\title{
ENERGY CONSUMPTION AND PROCESS EFFICIENCY AS AFFECTED BY EXTRUSION-COOKING CONDITIONS AND RECIPE FORMULATION DURING THE PRODUCTION OF GLUTEN-FREE RICE-LEGUMES PRODUCTS
}

\author{
Abdallah Bouasla ${ }^{\mathrm{a}}$, Agnieszka Wójtowicz ${ }^{\mathrm{b}^{*}}$, Stanisław Juśko ${ }^{\mathrm{b}}$, \\ Mohammed Nasreddine Zidoune ${ }^{\mathrm{a}}$ \\ ${ }^{a}$ Laboratoire de Nutrition et Technologie Alimentaire (LNTA), \\ Institut de la Nutrition, de l'Alimentation et des Technologies Agro-Alimentaires (INATAA), \\ Université des Frères Mentouri Constantine, Algeria \\ ${ }^{\mathrm{b}}$ Department of Food Process Engineering, University of Life Sciences in Lublin \\ *Corresponding author: e-mail: agnieszka.wojtowicz@up.lublin.pl
}

\begin{tabular}{|c|c|}
\hline ARTICLE INFO & ABSTRACT \\
\hline $\begin{array}{l}\text { Article history: } \\
\text { Received: October } 2016 \\
\text { Received in the revised form: } \\
\text { December } 2016 \\
\text { Accepted: January } 2017 \\
\end{array}$ & $\begin{array}{l}\text { The objective of the study was to determine the effect of extrusion- } \\
\text { cooking conditions (moisture content and screw speed) and recipe } \\
\text { formulation on process efficiency and energy consumption during the } \\
\text { extrusion-cooking of gluten-free rice-legumes products, shaped for } \\
\text { spaghetti-type pasta. Process efficiency }(Q) \text { was determined through }\end{array}$ \\
\hline $\begin{array}{l}\text { Key words: } \\
\text { extrusion-cooking, } \\
\text { gluten-free products, } \\
\text { process efficiency, } \\
\text { SME }\end{array}$ & $\begin{array}{l}\text { measurement of the pasta weight and energy consumption was deter- } \\
\text { mined using specific mechanical energy consumption }(S M E) \text {. Accor- } \\
\text { ding to the obtained results, screw speed had a great significant impact } \\
\text { on } Q \text { and } S M E \text { values which increased as screw speed increased. } \\
\text { Moisture content of raw materials had also a significant effect on } Q \\
\text { and } S M E \text { mainly at low screw speed applied. The process efficiency } \\
\text { increased with the increase of raw materials moisture content while } \\
\text { reverse observations were noted for the energy consumption. On the } \\
\text { contrary, variations of recipe formulations did not affect the measured } \\
\text { parameters. }\end{array}$ \\
\hline
\end{tabular}

\section{Introduction}

Gluten-free products, usually made of rice and corn, have weak nutritional composition including low protein and low fiber content (Thompson, 2009). Due to their interesting amount of protein, fiber, vitamins and minerals, legumes could be incorporated in glutenfree food to enhance their nutritional quality (Duranti, 2006; Gularte et al., 2012).

Extrusion-cooking represents a suitable technique for the production of gluten-free pasta (Marti and Pagani, 2013; Bouasla et al., 2016). Extrusion-cooking is a high-temperatureshort-time treatment which has a significant positive impact on the nutritional quality of the products (Alonso et al., 2000; Shimelis and Rakshit, 2007). In addition, products characteristics are related to recipe formulation and the extrusion-cooking conditions (Wójtowicz and Mościcki, 2009; Wójtowicz and Mościcki, 2014). 
The objective of the study was to determine the effect of extrusion-cooking conditions (moisture content and screw speed) and recipe formulation on process efficiency and energy consumption during the processing of rice-legumes pasta products.

\section{Materials and methods}

\section{Raw materials}

Raw materials used in this study were rice flour (purchased from Lubella Sp. z o.o. S. K., Lublin, Poland) and legumes seeds (yellow pea, chickpea, and red lentil) bought from local market. These seeds were ground with laboratory grinder TestChem (Radlin, Poland) and sifted to obtain flours with granulation below $0.5 \mathrm{~mm}$.

\section{Pasta processing}

Blends containing 2/1 (w/w) rice/yellow pea flours were prepared to determine the effect of extrusion-cooking conditions on energy consumption during the processing of rice-yellow pea pasta. For this purpose, flours were moistened with three different moisture contents $(28,30$, and $32 \%)$ and were produced using three screw speeds $(60,80$, and 100 rpm).

Regarding the determination of the effect of the recipe formulation on energy consumption, nine recipes were prepared by mixing rice flour with different amounts of yellow pea flour, chickpea flour, or lentil flour (10,20, and 30\%). Rice flour was considered as control. All blends were moistened up to $30 \%$ of dough moisture content and processed at $80 \mathrm{rpm}$.

The modified single screw extrusion-cooker type TS-45 (ZMCh Gliwice, Poland) was used to produce all gluten-free pasta products (Juśko et al., 2009). Using the barrel configuration of $\mathrm{L} / \mathrm{D}=18: 1$, the temperatures were set at $90 / 100 / 70^{\circ} \mathrm{C}$ in the first/second/final extruder sections. Spaghetti-type pasta products were formed and then dried to the moisture content below 12\% (Bouasla et al., 2016; Bouasla et al., 2017).

\section{Process efficiency}

The efficiency of extrusion-cooking of rice-legumes pasta products was determined in triple by measuring the mass of each pasta product at a specified time for every change in the process conditions (screw speed and moisture content of raw materials) and for each blend. The process efficiency $(Q)$ was calculated according to the formula (Kręcisz, 2016):

$$
Q=\frac{m}{t} \quad\left(\mathrm{kgh}^{-1}\right)
$$

where:

$m \quad$ - mass of pasta obtained during the measurement, $(\mathrm{kg})$

$t \quad$ - measurement time, (h) 
Energy consumption...

\section{Specific mechanical energy}

A standard register connected to the extruder's motor was used to measure the power consumption at each variation in the extrusion-cooking conditions and for each blend in three replications. The motor load was determined according to the extruder characteristics. The specific mechanical energy consumption ( $S M E$ ) was calculated with the method described by Ryu and Ng (2001) using the following formula:

$$
S M E=\frac{n}{N} \cdot \frac{L}{100} \cdot \frac{P}{Q}\left(\mathrm{kWh} \cdot \mathrm{kg}^{-1}\right)
$$

where:

$$
\begin{array}{ll}
n & \text { - screw speed used, }(\mathrm{rpm}) \\
N & \text { - maximum screw speed, }(\mathrm{rpm}) \\
L & \text { - motor load, }(\%) \\
P & \text { - motor electrical power, }(\mathrm{kW}) \\
Q & \text { - process efficiency, }\left(\mathrm{kg}^{-1} \mathrm{~h}^{-1}\right)
\end{array}
$$

\section{Statistical analysis}

One-way analysis of variance (ANOVA) followed by the Tukey's test was used to analyze the statistical differences between the mean values. Two-way ANOVA was used to determine the effect of extrusion-cooking conditions on energy consumption during the processing of rice-legumes pasta. Statistical analysis was carried out with Statistica 10 (StatSoft. Inc., Tulsa, OK, USA) at the $\alpha=0.05$ significance level.

\section{Results and discussion}

\section{Effect of extrusion-cooking conditions on $Q$ and SME during the processing of rice-yellow pea pasta products}

During the processing of rice-yellow pea pasta products, the process efficiency varied from 10.56 to $16.8 \mathrm{~kg} \cdot \mathrm{h}^{-1}$. The highest value was recorded for pasta processed at $28 \%$ of moisture content and $100 \mathrm{rpm}$ while the lowest one was recorded for pasta products produced from raw materials with moisture content of $28 \%$ and screw speed of $60 \mathrm{rpm}$. Twoway ANOVA showed a high significant effect of screw speed on process efficiency (Table 1). $Q$ values increased with the increase of screw speed used ( $\mathrm{r}=0.78, \mathrm{p}<0.0001)$ (Fig. 1).

$S M E$ during the processing of rice-yellow pea pasta ranged from 0.14 to $0.35 \mathrm{kWh}^{-1}$. The highest value of SME reported for pasta processed at $30 \%$ of moisture content and $100 \mathrm{rpm}$. The lowest value of $S M E$ was reported for pasta produced at $32 \%$ of moisture content and $60 \mathrm{rpm}$. The results of two-way ANOVA highlighted a high significant effect of screw speed on SME. This parameter increased as screw speed increased $(\mathrm{r}=0.96$, $\mathrm{p}<0.0001$ ) (Fig. 2). Similar results were reported by Wójtowicz and Mościcki (2008) for extruded precooked wheat pasta and by Kręcisz (2016) for extruded instant corn gruels. 
A. Bouasla, A. Wójtowicz, S. Juśko, M. N. Zidoune

Table 1.

Two-way ANOVA for process efficiency (Q) and specific mechanical energy (SME)

\begin{tabular}{lcccccc}
\hline Parameter & Source of variation & DF & SS & MS & $F$ & p-value \\
\hline \multirow{2}{*}{$Q$} & Moisture content $(M)$ & 2 & 2.342 & 1.171 & 10.23 & 0.001078 \\
$\left(\mathrm{kgh}^{-1}\right)$ & Screw speed $(S)$ & 2 & 74.458 & 37.229 & 325.14 & 0.000000 \\
& $M \times S$ & 4 & 16.896 & 4.224 & 36.89 & 0.000000 \\
& Error & 18 & 2.061 & 0.115 & & \\
$S M E$ & Moisture content $(M)$ & 2 & 0.001119 & 0.000559 & 6.04 & 0.009839 \\
$\left(\mathrm{kWh} \cdot \mathrm{kg}^{-1}\right)$ & Screw speed $(S)$ & 2 & 0.132985 & 0.066493 & 718.12 & 0.000000 \\
& $M \times S$ & 4 & 0.003504 & 0.000876 & 9.46 & 0.000267 \\
& Error & 18 & 0.001667 & 0.000093 & & \\
\hline
\end{tabular}

Moisture content had also a significant effect on $Q$ and $S M E$ during the production of rice-yellow pea pasta. At low screw speed, $Q$ increased as moisture content increased. On the contrary, $S M E$ decreased slightly with the increase of moisture content. Similar observations were reported in literature (Ryu and Ng, 2001; Wójtowicz and Mościcki, 2008; Giménez et al., 2013). This phenomenon is related to the lubrificant effect caused by high moisture, resulting in less friction and shearing stress inside the extruder, and, as a consequence, less transferred enegy (Duarte et al., 2009; Pérez et al., 2008).

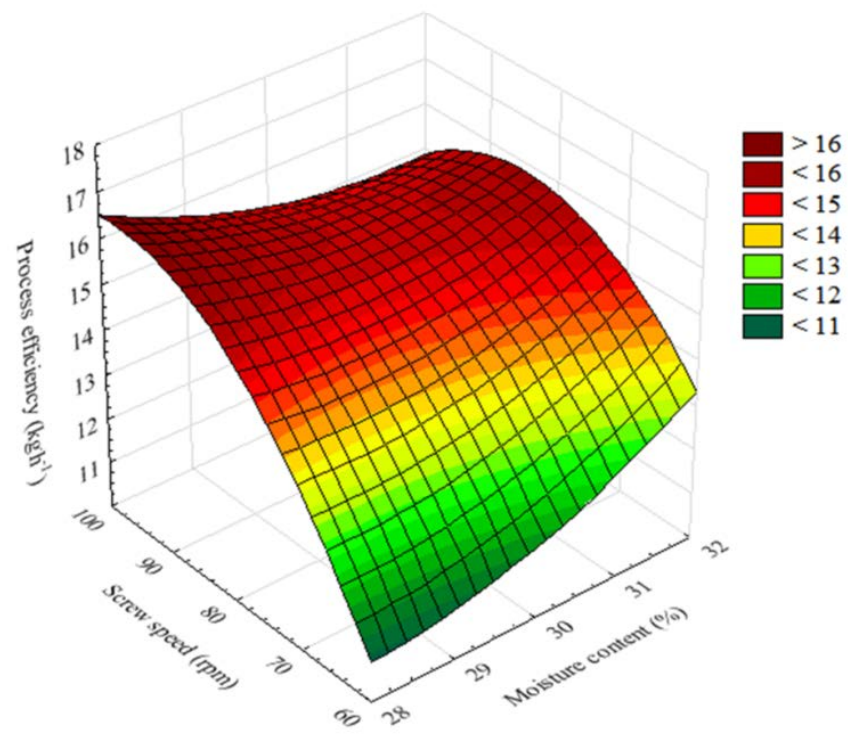

Figure 1. Process efficiency during the processing of rice-yellow pea pasta products as affected by moisture content and screw speed. 


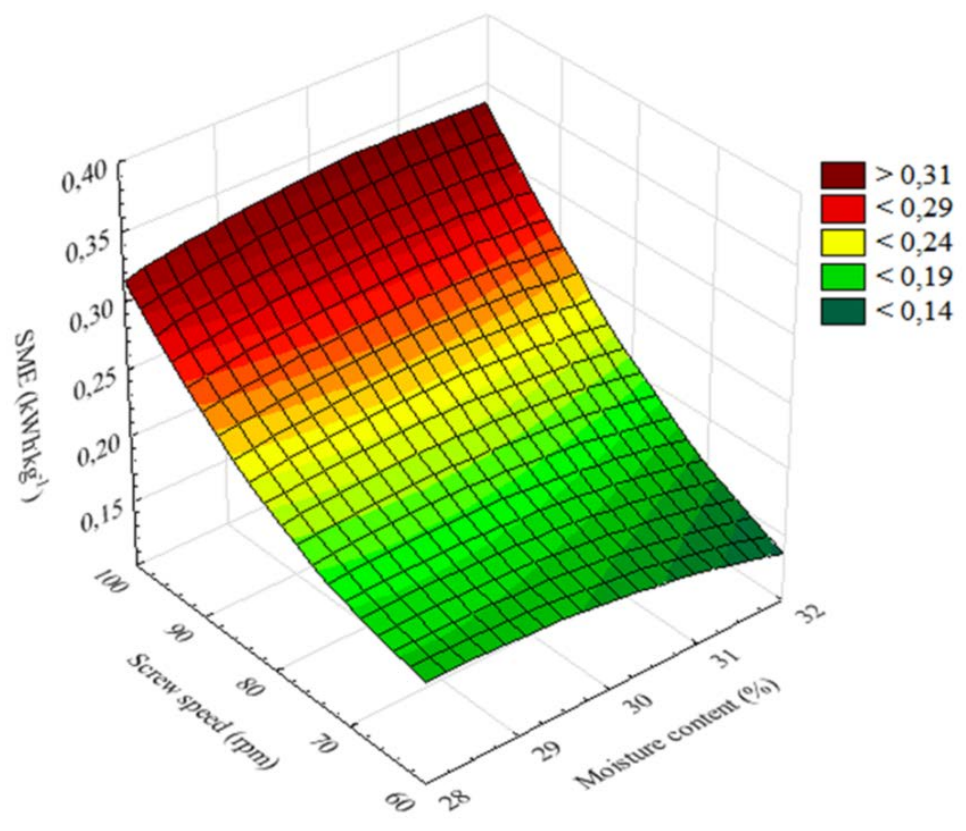

Figure 2. Specific mechanical energy during the processing of rice-yellow pea pasta pro-ducts as affected by moisture content and screw speed.

Effect of recipe formulation on $Q$ and $S M E$ during the processing of rice-legumes pasta products

Table 2 shows process efficiency and SME values during the extrusion-cooking of rice pasta and rice pasta enriched with legumes flours. Increasing the amount of legumes flours in the recipes did not affect significantly the process efficiency and the SME during the processing of gluten-free pasta. Process efficiency ranged from 12.00 to $12.96 \mathrm{~kg} \cdot \mathrm{h}^{-1}$, while $S M E$ ranged from 0.25 to $0.27 \mathrm{kWh} \cdot \mathrm{kg}^{-1}$. Similar observations were reported by Wójtowicz and Mościcki (2014) for precooked pasta produced from wheat flour with yellow pea and lentil flours. 
A. Bouasla, A. Wójtowicz, S. Juśko, M. N. Zidoune

Table 2.

Process efficiency and specific mechanical energy of rice pasta and rice pasta products enriched with legumes flours

\begin{tabular}{lccc}
\hline & $\begin{array}{c}\text { Amount } \\
(\%)\end{array}$ & $\begin{array}{c}Q \\
\left(\mathrm{kgh}^{-1}\right)\end{array}$ & $\begin{array}{c}S M E \\
\left(\mathrm{kWh}^{-1}\right)\end{array}$ \\
\hline Rice & 0 & $12.48^{\mathrm{a}}$ & $0.26^{\mathrm{a}}$ \\
Yellow pea & 10 & $12.00^{\mathrm{a}}$ & $0.27^{\mathrm{a}}$ \\
& 20 & $12.00^{\mathrm{a}}$ & $0.27^{\mathrm{a}}$ \\
& 30 & $12.48^{\mathrm{a}}$ & $0.26^{\mathrm{a}}$ \\
Chickpea & 10 & $12.00^{\mathrm{a}}$ & $0.27^{\mathrm{a}}$ \\
& 20 & $12.00^{\mathrm{a}}$ & $0.27^{\mathrm{a}}$ \\
& 30 & $12.00^{\mathrm{a}}$ & $0.27^{\mathrm{a}}$ \\
Lentil & 10 & $12.00^{\mathrm{a}}$ & $0.27^{\mathrm{a}}$ \\
& 20 & $12.96^{\mathrm{a}}$ & $0.25^{\mathrm{a}}$ \\
& 30 & $12.00^{\mathrm{a}}$ & $0.27^{\mathrm{a}}$ \\
\hline
\end{tabular}

$\mathrm{a}, \mathrm{b}$ - the same letters in columns indicate homogeneous groups according to Tukey’s test

\section{Conclusions}

According to the presented results, we obtained the following conclusions:

1. Screw speed had a great significant impact on both process efficiency and SME during gluten-free pasta processing with the extrusion-cooking. The two parameters values increased with the increase of screw speed.

2. Moisture content showed also significant impact on process efficiency and SME mainly at low screw speed. Increasing the moisture content caused an increase in process efficiency while increased moisture content decreased the SME.

3. Addition of legumes flour up to $30 \%$ in blends did not affect the process efficiency and the $S M E$ during the processing of rice-legumes pasta.

\section{References}

Alonso, R., Aguirre, A., Marzo, F. (2000). Effects of extrusion and traditional processing methods on antinutrients and in vitro digestibility of protein and starch in faba and kidney beans. Food Chemistry, 68, 159-165.

Bouasla, A., Wójtowicz, A., Zidoune, M. N., Olech, M., Nowak, R., Mitrus, M., Oniszczuk, A. (2016). Gluten-free precooked rice-yellow pea pasta: effect of extrusion-cooking conditions on phenolic acids composition, selected properties and microstructure. Journal of Food Science, 81(5), 1070-1079.

Bouasla, A., Wójtowicz, A., Zidoune, M. N. (2017). Gluten-free precooked rice pasta enriched with legumes flours: Physical properties, texture, sensory attributes and microstructure, LWT - Food Science and Technology, 75, 569-577.

Duarte, G., Carvalho, C., Ascheri, J. (2009). Effect of soybean hull, screw speed and temperature on expanded maize extrudates. Brazilian Journal of Food Technology, 12, 205-212. 
Duranti, M. (2006). Grain legume proteins and nutraceutical properties. Fitoterapia, 77(2), 67-82.

Giménez, M. A., González, R. J., Wagner, J., Torres, R, Lobo, M. O., Samman, N. C. (2013). Effect of extrusion conditions on physicochemical and sensorial properties of corn-broad beans (Vicia faba) spaghetti type pasta. Food Chemistry, 136, 538-545.

Gularte, A. M., Gomez, M., Rosell, C.M. (2012). Impact of legume flours on quality and in vitro digestibility of starch and protein from gluten-free cakes. Food Bioprocess Technology, 5, 31423150.

Juśko S., Mościcki L., Wójtowicz A. (2009). Cooling-forming section. Design Patent PL64690Y1. Patent Office Bulletin (BUP), 2(195), 25.

Kręcisz, M. (2016). Energy consumption during production of corn extrudates in relation to the process parameters. Agriculture Engineering, 20(7), 195-203.

Marti, A., Pagani, M. A. (2013). What can play the role of gluten in gluten free pasta? Trends in Food Science and Technology, 31, 63-71.

Pérez, A. A., Drago, S. R., Carrara, C. R., De Greef, D. M., Torres, R. L., González, R. J. (2008). Extrusion cooking of a maize/soybean mixture: Factors affecting expanded product characteristics and flour dispersion viscosity. Journal of Food Engineering, 87, 333-340.

Ryu, G. H., Ng, P. K. (2001). Effect of selected process parameters on expansion and mechanical properties of wheat flour and whole cornmeal extrudates. Starch/Stärke, 53, 147-154.

Shimelis, E. A., Rakshit, S. K. (2007). Effect of processing on antinutrients and in vitro digestibility of kidney bean (Phaseolus vulgaris L.) varieties grown in East Africa. Food Chemistry, 103, 161-172

Thompson, T. (2009). The nutritional quality of gluten-free foods. In E. Gallagher (Ed.), Gluten-free food science and technology (pp. 42-51). London: Blackwell Publishing Ltd.

Wójtowicz, A., Mościcki, L. (2008). Energy consumption during extrusion-cooking of precooked pasta. TEKA. Commission Motorization and Energetics in Agriculture, 8, 311-216.

Wójtowicz, A., Mościcki, L. (2009). Influence of extrusion-cooking parameters on some quality aspects of precooked pasta-like products. Journal of Food Science, 74, 226-233

Wójtowicz, A., Mościcki, L. (2014). Influence of legume type and addition level on quality characteristics, texture and microstructure of enriched precooked pasta. LWT - Food Science and Technology, 59, 1175-1185. 


\section{ZAPOTRZEBOWANIE ENERGII I WYDAJNOŚĆ PROCESU W ZALEŻNOŚCI OD PARAMETRÓW EKSTRUZJI I SKŁADU SUROWCOWEGO PODCZAS WYTWARZANIA RYŻOWO-STRĄCZKOWYCH WYROBÓW BEZGLUTENOWYCH}

Streszczenie. Celem pracy było wyznaczenie wpływu parametrów procesu ekstruzji (poziomu dowilżenia i prędkości obrotowej ślimaka) a także składu surowcowego receptury na wydajność procesu oraz zapotrzebowanie energii podczas ekstruzji bezglutenowych mieszanek ryżowo-strączkowych w postaci nitek makaronowych. Wydajność procesu $(Q)$ wyznaczono przez pobranie masy wytworzonego ekstrudatu w określonym czasie, zaś energochłonność procesu wyznaczono przez wyliczenie jednostkowego zapotrzebowania energii mechanicznej ( $S M E)$. Na podstawie uzyskanych wyników stwierdzono, że prędkość obrotowa ślimaka miała bardziej istotny wpływ na wartości $Q$ i $S M E$ niż zmienny poziom dowilżenia mieszanek surowcowych oraz interakcje pomiędzy tymi parametrami. Wartości $Q$ i $S M E$ zwiększały się wraz ze zwiększaniem prędkości ślimaka podczas ekstruzji. Poziom dowilżenia surowców miał również istotny wpływ na wydajność i energochłonność wytwarzania ekstrudowanych makaronów bezglutenowych, zwłaszcza przy niskich prędkościach ślimaka. Wydajność procesu ekstruzji zwiększała się wraz ze zwiększaniem poziomu dowilżenia mieszanek surowcowych, te zależności nie były jednak obserwowane podczas wyznaczania energochłonności procesu. Zastosowanie zróżnicowanych receptur surowcowych przy jednakowych parametrach wytwarzania nie miało wpływu zarówno na wydajność, jak i energochłonność procesu ekstruzji wyrobów bezglutenowych.

Słowa kluczowe: ekstruzja, produkty bezglutenowe, wydajność procesu, SME 